\title{
Advancement, Simplification and Piloting of Electrical Proso Millet De- Husker (Chino Kutak)
}

\author{
Ganga Ram Bhandari ${ }^{1 @}$, Devendra Gauchan ${ }^{2}$, Bharat Bhandari ${ }^{3}$, Bal Krishna Joshi ${ }^{4}$ and Saroj Panta ${ }^{3}$ \\ ${ }^{1}$ Nepal Agricultural Research Council, National Agricultural Research Center, Lalitpur, Nepal; @ : \\ gangarambhandari.narc@gmail.com; (D): https://orcid.org/0000-0002-1341-8460 \\ ${ }^{2}$ Alliance of Bioversity International and CIAT, Kathmandu, Nepal: d.gauchan@cgiar.org \\ ${ }^{3}$ LI-BIRD, Nepal; bbhandari@libird.org; SP: saroj.pant@libird.org \\ ${ }^{4}$ National Genetic Resource Center, Lalitpur, Nepal; joshibalak@yahoo.com
}

Received 12 November, 2020, Revised 16 February, 2021, Accepted 25 March, 2021, Published 30 April, 2021

Scientific Editors: Jiban Shrestha, Subash Subedi

Copyright $\odot 2021$ NARC. Permits unrestricted use, distribution and reproduction in any medium provided the original work is properly cited.

The authors declare that there is no conflict of interest.

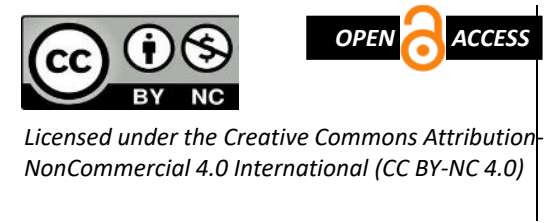

\section{ABSTRACT}

Proso millet is a minor cereal crop commonly cultivated in rain fed marginal uplands particularly in the mid and far western mountain region of Nepal. It is potential crop for ensuring food and nutrition security and conservation of local crop biodiversity in high mountain region. Traditionally Proso millet (locally as chino) is processed manually on Mortar and Pestle (Okhal) by using muscular power. However, dehusking (pearling) of Proso millet is very tedious job. The traditional method of processing takes 1 hour to dehusk $2 \mathrm{~kg}-3 \mathrm{~kg}$ of Proso millet for two women and cause lots of physical exertion to them. Therefore, GEF UNEP Local Crop Project in collaboration with Agricultural Engineering Divisionof NARC initiated program in 2017to design, fabricate and test electric Proso Millet de-husking machine (called chino kutak) that is safe and economical in operation for the use of the local farmers of remote Himalayan region. The model-1 designed, fabricated and piloted at Humla (Chhipra, Kharpunath Rural Municipality) in 2018 was improvised version of Finger millet processing machine. The Model-2 was based on the Centrifugal type working on impact principle was developed in January 2020. The Model-2 was very much successful in all variety of Proso millet and higher capacity up to $52.5 \mathrm{~kg} / \mathrm{hr}$.it is equally applicable to other millets.

Keywords: Centrifugal, chino Kutak, de-husking, drudgery, impact

सारांश

नेपालको मध्य तथा पश्चिमी उच्च पहाडी क्षेत्रमा खासगरी सुक्खा बारीमा खेति गरिने चिनो एक खाद्यान्न वाली हो 1 यो खाद्यान्न वालीले खाध्य तथा पोषण सुरक्षा र जैबिक बिबिधता संरक्षणमा योगदान पुराउन सक्ने वालीको रुपमा लिन सकिन्छ 1 परम्परागतरुपमा चिनो लाइविशेषगरी महिलाहरुले ओखलमा शारीरिक वलको मद्दतले कुटेर प्रशोधन गर्ने चलन रहेको पाइन्छ 1 यसरी परम्परागत रावर्ले प्रशोधन गर्दा दुइजना महिलाले एक घण्टामा २-३ किलोग्राम मात्र चिनो कुट्ने साथै शारीरिक कस्ट पनि हुने गर्दथ्यो 1 यसै कुरालाई मध्यनजर गर्दे स्थानीय वाली परियोजनाको सहकार्यमा साबिक कृषि इन्जिनियरिंग महाशाखाले सन् २०१७/१८ मा बिधुतिय चिनो कुट्ने मेशिन को बिकाश गर्यो जुन दुर्गम हिमाली क्षेत्रका किसानको लागि सस्तो एबम सुरक्षित प्रबिधि थियो ।मोडेल -१ चिनो कुटक मेशिन जुन कोदो कुट्ने मेशिनको सिद्दान्तमा थप सुधार गरि बनेको थियो त्यसलाई हुम्ला जिल्लाको खर्पुनाथ गाउपालिका छिप्रा भन्ने ठाउमा सन् २०९८ मा परिक्षण गरियो 1 त्यस्तै मोडेल-२ चिनोकुटक सेन्ट्रीफ्युगल फोर्स को सिद्दान्तमा काम गर्ने मेशिन सन् २०२० मा निर्माण एबम परिक्षण गरियो र यो मेशिन को कार्य दक्षता ५२.५ किलोग्राम प्रतिघन्टा पाइएको छ 1

\section{INTRODUCTION}

The Pros millet (Panicum miliaceum L.) commonly known as chino is a cereal crop cultivated as a grain crop in the Himalayas up to the altitude 3500meterasl. In Nepal it is cultivated in the marginal lands in temperate region that is further North than any other millets are grown. Pros millet is a staple 
food and cultivated as main cereal grain in the mountain regions of mid and far western Nepal (Joshi et al 2019). Proso millet is an erect annual grass up to $145-155 \mathrm{~cm}$ tall, usually free-tillering and tufted, with a rather shallow root system. Its productivity in Nepal is $60-70 \mathrm{~kg} / \mathrm{ropani}\left(500 \mathrm{~m}^{2}\right)$ (Prajulietal 2016)). The grains are very small and oval in shape up to $3 \mathrm{~mm}$ long and $2 \mathrm{~mm}$ width, smooth. Seed color is wide ranging and can be white, cream, yellow, orange, red, and black through to brown. It is completely gluten-free and is packed with a variety of essential minerals, potassium in particular, which contributes to nervous system health (Joshi et al 2020). The important popular local varieties of Proso millet in Humla are black, red, milky and hardy varieties often locally named askalo chino, rato chino, Dudhe chino, haande chino in Nepali language (Joshi and Ghimire 2015, Rawal et al 2019).

Millets contain a dry external cover called husk. Removal of the husk is called De-husking (Prashant et al 2015). The removal of the husk layer thus becomes the primary task of processing of these grains for obtaining grain (naked grain) and for further processing of grains for consumption. Once removed, we get the Proso millet ready to cook. Proso millet is consumed as Proso millet (like rice), pudding, and porridge and can be eaten after beaten and milling as flour. Proso millet seeds are enclosed in the hulls, and difficult to remove by conventional milling processes. The de-husking of Proso millet has been considered as a tedious and time-consuming work which is generally done by women farmers. However, currently, appropriate de-husking machines are not available. Traditionally in the rural areas of Nepal Proso millet is de-husked (removal of outer coat of seed) in Mortar and Pestle (Okhal) by using muscular power. The power levels that can be produced by an average healthy athlete are 75W maximum (Modak and Bapat 1987). The major challenges in processing Proso millet are: i) The small size of the grains and irregular shape of grain ii) Variations in the raw materials due to variation in varieties across production regions iii) Low shelf life of the processed rice and grits due to pest infestation and rancidity iv) Hard, slippery outer coat of seed (husk) than found in other millets (DHAN Foundation 2016).

The field study in Chhipra, Humla in 2019 revealed that the traditional method of processing takes 1 hour to de-husk $2 \mathrm{~kg}$ to $3 \mathrm{~kg}$ of Proso millet for two women (Bhandari et al 2020). They can de-husk only $20-30 \mathrm{~kg}$ in a day by two women and cause lots of physical exertion to them. Considering the strong need of the processing machine for the Proso Millet, the Local Crop Project ${ }^{1}$ in Nepal has studied the problem, designed and piloted electric processing machine (de-husker, called chino kutak) in the project site in Humla. The main objective of this research was to develop the electrically operated processing machine which has high de-husking and milling efficiency and would reduce the physical drudgery and work load of women. This paper aims to outline the process and results of fabrication, improvement and piloting of Proso millet processing system which targets smallholder farmers in the western high mountains (Karnali Province) of Nepal. This paper also presents the experiences and lesson learned in the development and filed piloting of Model-1 Proso millet dehusker and the successful designing and testing the improved version of Model-2 de-husker suited to all types of Proso millet varieties including foxtail millet.

\section{MATERIALS AND METHODS}

To simplify the processing of Proso millet, some bio-physical properties were studied. Prototype development and lab testing was conducted at Kathmandu and piloting site was Humla, one of the Local Crop Project sites. At first studied and tried different De-husking/de-hulling technologies are namely, 1. Emery stone mill working on abrasion principle which was under research at Agricultural Engineering Division $(\mathrm{AED})^{2}$, 2. Rubber roller mill working on abrasion principle and 3. Centrifugal type working on impact principle. The Model-1was designed and fabricated at AED with the financial support and facilitation of GEF UNEP Local Crop Project (LCP) in the year 2017. The project was

\footnotetext{
${ }^{1}$ Local Crop Project is a local project name coined for farmers and stakeholders Nepal for the Global Environment Facility (GEF) and United National Environment Program (UNEP) funded project entitled "Integrating traditional crop genetic diversity into new technology:

${ }^{2}$ Agricultural Engineering Division has been changed to National Agricultural Engineering Research Centre from July 16,2020
} 
successful in designing, fabrication and testing the electric Proso millet machine locally named as chino kutak Model-1 in September 2018 (Bhandari et al 2020). After testing the machine at AED, the field performance evaluation and demonstration were carried out in Kharpunath Rural Municipality-4 Nalla village (chhipra) in Humla district, Nepal. To overcome the limitations of Model-1, the Model-2 was developed. The Model-2 machine was also designed and fabricated at AED with the financial support and facilitation of LCP. The project was successful in designing, fabrication and testing the electric proso millet machine locally named as chino kutak Model-2 in January 2020. After getting the failure with emery stone mill working on abrasion principle which was under research at AED, the Model -1 was designed working on abrasion principle with replaceable stoppers andModel-2 was designed as Centrifugal type working on impact principle. With the application of appropriate processes, resources and tool, the Proso millet de-husking machine was fabricated by selecting suitable materials for each component. After making the components it was assembled as per our design. The machine was tested at AED for different moisture contents and feed rates of Proso millet and fox tail millet, too.

For lab testing of machine Moisture content of Proso millet before de-husking was measured using digital moisture meter. Grain was sun dried the day before the de-husking. Treatment with calcium hydroxide and with high moisture content was also done. For field performance evaluation, Model-1 machine was tested in Kharpunath Rural Municipality 4, Nalla, Humla for the evaluation of its overall performance in terms of productivity, efficiency and capacity. Conclusions were drawn based on the results of the field performance test of the prototype and farmers reactions based on which suitable recommendations are given. Model-2 was tested at Khumaltar in presence of Locals from Humla District. It was tested for hard red chino and foxtail millet also. The de-husking capacity, de-husking efficiency, head grain yield, broken yield and milling efficiency were calculated. The following indices were used to evaluate the performance of machine.

$$
\begin{aligned}
& \text { Dehusking efficiency } \%=\frac{A}{B} \times 100 \\
& \text { Broken } \%=\frac{D}{A} \times 100 \\
& \text { Head grain yield } \%=\frac{C}{A} \times 100 \\
& \text { Milling efficiency } \%=\frac{\mathrm{E} \times \mathrm{F}}{100}
\end{aligned}
$$

Where,

A- Weight of milled grains (head grain and broken garain) (g)

B- Weight of grains fed to the machine $(\mathrm{g})$

C- Weight of head grains (g) (dehusked grain)

D- Weight of broken grains (g)

E- Dehusking efficiency

F-Head grain yield

The performance evaluation of Model-1 is carried out for different verities, moisture content, and application of $2 \%$ lime water.

T-1: mixed type chino at moisture content $11.4 \%$

T-2: Mixed type chino with application of $2 \%$ lime water for two hour, sun drying and dehusking at moisture content $14 \%$

T-3: Dudhe chino at moisture content $10.4 \%$

T-4: Dudhe chino at moisture content $12.4 \%$

The performance evaluation of Model-2 is carried out for different verities, moisture content and water treatment.

T-1: mixed type chino at moisture content $11.4 \%$

T-2: Rato chino with water treatment for two-hour, sun drying and de-husking at moisture of $14 \%$

T-3: Rato chino at moisture content $10.4 \%$

T-4: Rato chino at moisture content $12.4 \%$ 


\section{Major components and components design}

Major components of Model-1

Power unit: The De-husker was operated by single phase electrical motor. A motor power of $1.5 \mathrm{hp}$ was assumed for power requirement. So, throughout the design of all the components, it is taken as the input power to the machine and considers all frictional losses to be negligible. Normally, a $1.5 \mathrm{hp}$ motor has a speed of $1420 \mathrm{rpm}$ (Revolution per minute).

Hopper: hopper is placed at the top of machine and made up of MS Sheet metal. Feeding unit is made in such a way that grain is fed into threshing unit from throughout the length of threshing cylinder. Flow control rate or feed rate control mechanism is provided just below the hopper.

De-husking drum: This unit consists of rotating threshing cylinder on a shaft driven by electric motor. it is made of cast iron and it is housed inside the threshing chamber. Numbers of stoppers are provided on the periphery as well as on the body of the de-husking drum. Stoppers on the rotating drum are made of general flat belt material. The speed of de-husking drum shaft is maintained at 460 rpm with the arrangement of proper Belt - pulley transmission ratio. At the bottom of the de-husking drum a screen with circular hole is provided through which mixture of threshed grain with husk get out. De-husking drum cover is made up of MS Sheet metal.

Separation unit: This unit consists of two screens with round hole of different sizes. It is shaken by the power from the electric motor. The speed of shaking shaft is maintained $720 \mathrm{rpm}$. Oversized portion goes out from first spout, material passed from top screen and retained on second are goes out from second spout and those which passes from second screen goes out from third spout outlet. Screens sets have been provided with 30-degree slope.

\section{Component design}

To remove the husk from the grain, one can use two forces - impact or shear. A stone grinding mill, manual or motor powered employs the shear force while manual pounding or centrifugal hulling machines use the impact force. The power required to thresh grains from the millet panicles is expressed as:

$\mathrm{P}=\mathrm{T} \times \omega=\mathrm{T} \times 2 \pi \mathrm{N} / 60$ watts

Where,

$\mathrm{P}=$ is the power required (watts)

$\mathrm{T}=$ torque of the drum $(\mathrm{Nm})$

$\omega=$ angular velocity $(\mathrm{rad} / \mathrm{s})$

$\mathrm{N}=$ speed of the threshing drum (rpm)

$\mathrm{F}=$ the impact force required to thresh millet

$\mathrm{r}=$ the distance of point of force application from axis of rotation $(\mathrm{m})$

The torque resulting from individual force is given by: $\mathrm{T}=\mathrm{F} \times \mathrm{r}$

Total torque $(\mathrm{T})$ on the drum was calculated as follows: $\mathrm{T}=\mathrm{Tr} \times \mathrm{Kb}$

Where, $\mathrm{Kb}$ is the number of beaters/stopper on the drum

Dimension and mechanical features of machine

Total height of machine $=116 \mathrm{~cm}$.

Diameter of drum $=36 \mathrm{~cm}$.

Electrical motor of $1.5 \mathrm{hp}$ and RPM=1420

RPM of de-husking drum $=460$

RPM of Shaking screen shaft $=720$

Slope of separation screen 30 degree

Number of separation screen used $=2$

Number of output collection $=3$ 


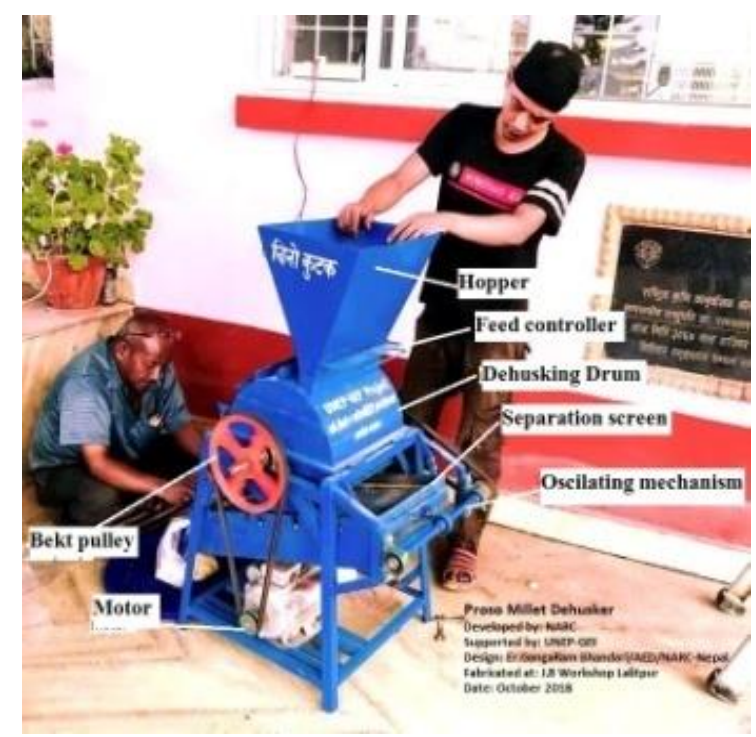

Figure1. Proso millet De-husker Model-1

\section{Major components of Model-2}

The Model-2 machine has the following units -power unit, feeding hopper, double shell de-husking drum and grain and husk outlet unit. With the application of appropriate processes, resources and tool, the Proso millet de-husking machine was fabricated by selecting suitable materials for each component. After making the components it was assembled as per our design.

Power unit: The De-husker was operated by single phase $2 \mathrm{hp}, 1540$ RPM electrical motor. Throughout the design of all the components, it is taken as the input power to the machine and considers all frictional losses to be negligible.

Hopper: hopper is placed at the top of machine and made up of M.S Sheet metal. Feeding unit is made in such a way that grain is fed into top rotating drum and made to spread all direction. Flow control rate or feed rate control mechanism is provided just below the hopper.

De-husking drum: This unit consists double shell drum; the inner rotating rubber cylinder on a shaft driven by electric motor. Inner and outer shell is separated by metallic screen which separates the husk and provide the impact base for grains. Outer shell is covered by MS sheet. Numbers of stoppers are provided on the body of the rotating rubber cylinder. The rotating rubber cylinder rotating at RPM of 2300 cerates the centrifugal force to the feed grain and resulting impact on the wall (metallic screen) cases the de-husking. At the bottom of the rotating cylinder the de-husked grain outlet was made and in the outer shell a husk outlet was made at the bottom of machine. At least three air inlet slots are made on the body of machine.

\section{Dimension and mechanical features of machine}

Total height of machine $=80 \mathrm{~cm}$;

Length: $65 \mathrm{~cm}$ (including motor frame); Width: $30 \mathrm{~cm}$

Diameter of drum $=30 \mathrm{~cm}$;

Electrical motor of $2 \mathrm{hp}$ and RPM $=1450$

$\mathrm{RPM}$ of rotating rubber cylinder $=2300$ 


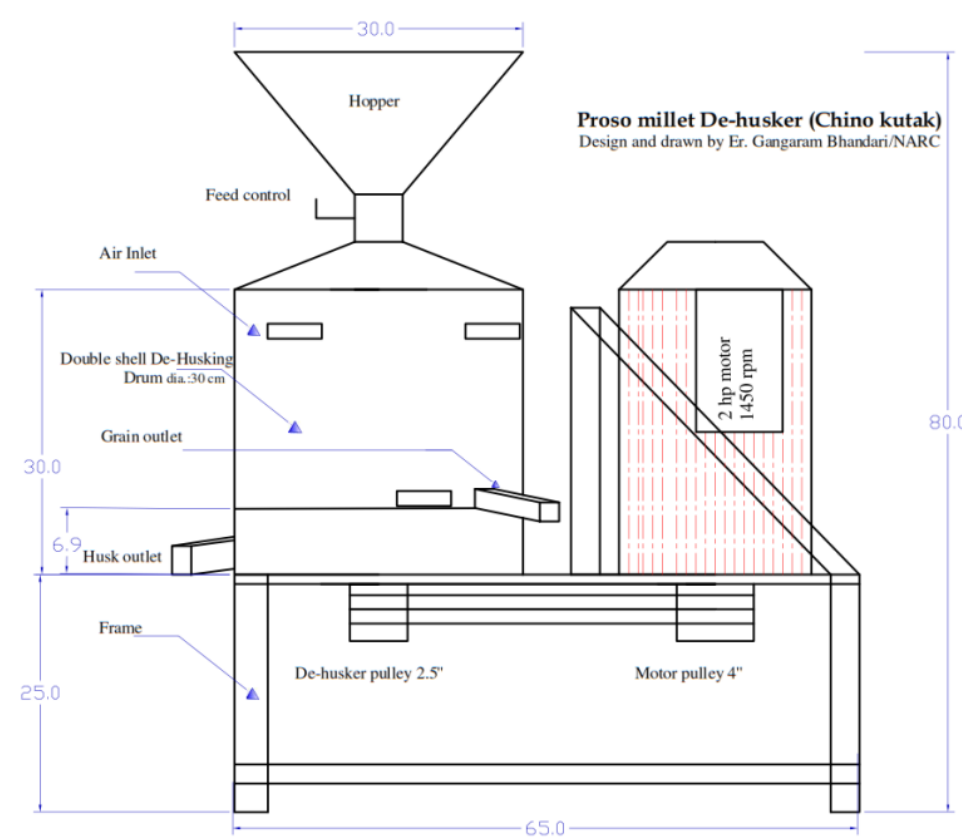

Figure2.Centrifugal type Proso millet De-husker Model-2

\section{RESULTS}

Table 1 and table 2 depict the different effects of processing methods and condition on the performance of de-husker. Milling efficiency was very low for lime water treated Proso millet. Milling efficiency was found highest for water treated chino and shows the quite satisfactory result for at moisture content $12.4 \%$ and poor result at low moisture content level.De-husking capacity for dehusker for treatment T2 showed highest. De-husker had low de-husking capacity at low moisture content. On an average Model-1 has de-husking capacity more than $33.5 \mathrm{~kg}$ per hour and Model-2 has more than $52.5 \mathrm{~kg}$ per hour.De-husking efficiency is higher for lime water treated or water treated Proso millet. Model-2 machine was found very successful for de-husking all varieties of Proso millet. Either water treatment and sun dried one day before milling or sun dried one day before milling at the moisture content $12-14 \%$ showed the good results. Power consumptions by machine was not too high and machine has overall good performance. The model-2 has no frequent changeable parts so it may have long life. It can reduce the cost of processing of Proso millet by $80 \%$ as compared to traditional processing. It has weight of about $60 \mathrm{~kg}$ including motor and frame is quite reasonable in transporting in remote areas.

Table1.Effects of variety and moisture contents and processing method on performance of Proso millet de-husker Model-1

\begin{tabular}{llllll}
\hline $\begin{array}{l}\text { De-husking } \\
\text { methods }\end{array}$ & $\begin{array}{l}\text { De-husking } \\
\text { capacity(kg/hr) }\end{array}$ & $\begin{array}{l}\text { De-husking } \\
\text { efficiency }(\%)\end{array}$ & $\begin{array}{l}\text { Head grain } \\
\text { yield (\%) }\end{array}$ & $\begin{array}{l}\text { Broken } \\
\text { yield (\%) }\end{array}$ & $\begin{array}{l}\text { Milling efficiency } \\
(\%)\end{array}$ \\
\hline T1 & 25 & 81 & 70 & 30 & 56.7 \\
\hline T2 & 38 & 85 & 60 & 40 & 51 \\
\hline T3 & 35 & 82 & 72 & 28 & 59 \\
\hline T4 & 36 & 84 & 75 & 25 & 63 \\
\hline Mean & 33.5 & 83 & 69.25 & 30.75 & 57.42 \\
\hline
\end{tabular}

Model-2 was tested at the Khumaltar with the presence of Locals from Humla districts for acceptance. Mixed type chino, rato chino at different moisture content and treatments are separately carried out. The observations on the crop feed amount, time, moisture content, broken grain percentage and various efficiencies are shown in table given below: 
Table2. Effects of variety and moisture contents and processing method on Proso millet de-husker Model2

\begin{tabular}{llllll}
\hline $\begin{array}{l}\text { De-husking } \\
\text { methods }\end{array}$ & $\begin{array}{l}\text { De-husking } \\
\text { capacity(kg per } \\
\text { hour) }\end{array}$ & $\begin{array}{l}\text { De-husking } \\
\text { efficiency }(\boldsymbol{\%})\end{array}$ & $\begin{array}{l}\text { Head grain } \\
\text { yield } \mathbf{( \% )}\end{array}$ & $\begin{array}{l}\text { Broken } \\
\text { yield }(\boldsymbol{\%})\end{array}$ & $\begin{array}{l}\text { Milling } \\
\text { efficiency } \\
(\boldsymbol{\%})\end{array}$ \\
\hline T1 & 55 & 88 & 70 & 30 & 61.6 \\
\hline T2 & 60 & 90 & 80 & 20 & 72 \\
\hline T3 & 45 & 86 & 70 & 30 & 60.2 \\
\hline T4 & 50 & 89 & 77 & 23 & 68.53 \\
\hline Mean & 52.5 & 92 & 74.25 & 25.75 & 65.58 \\
\hline
\end{tabular}

\section{DISCUSSION}

The Model-2 was found more effective and got the positive response from the farmers as well as processing entrepreneur from Humla. The model-1 was the improved version of electrical finger millet de-husking machine.Patil et al (2018) reported that de-husking efficiency of minor millet dehusker was affected by moisture content of feed, feed rate, speed of rotating cone and the clearance between de-husking cones. TheProso millet isvery difficult to de-hull because of smooth slippery as well as hard outer shell. The oval shape of grain created the problem to separate the un-hulled grain through screen separation method from hulled rice. Gravity separation also didn't work. Size of machine was preferred by locals because of transportation problems in remote area. Researcher reported that main character of grain for milling quality were the size, form, structure of grain, outer shell of grain and endosperm hardness. Balasubramanian and Viswanathan (2010) reported that grain hardness decreased from 30.7 to 12.4 for all minor millets when moisture content was increased from 11.1 to $25 \% \mathrm{db}$.Our results also showed the increased de-husking capacity at higher moisture content and water treated grain. We observed the high brittleness of endosperm of Proso millet at low moisture content level. The endosperm of Dudhe chino was very brittle more broken grains were found so needs slower speed in Model-1.

Prashant et al (2015) reported that Millets are store- house of nutrition (Table 3). Neglected crops but rich of nutrients could be highlighted through the availability of processing machinery. The model-1 has replaceable stopper for gap adjustment between stopper and screen. Model -1 can also be use for multipurpose use for de-husking minor millets. The model -2 doesn't need the frequent replacement of parts because it just imparts the rotating centrifugal force to the grain.

Table3. Nutrient content of millets

\begin{tabular}{llllll}
\hline Crop/Nutrient & Protein(g) & Fiber $(\mathbf{g})$ & Minerals $(\mathbf{g})$ & Iron $(\mathbf{m g})$ & Ca(mg) \\
\hline Pearl millet & 10.6 & 1.3 & 2.3 & 16.9 & 38 \\
\hline Finger millet & 7.3 & 3.6 & 2.7 & 3.9 & 344 \\
\hline Foxtail millet & 12.3 & 8 & 3.3 & 2.8 & 31 \\
\hline Proso millet & 12.5 & 2.2 & 1.9 & 0.8 & 14 \\
\hline Kodo millet & 8.3 & 9 & 2.6 & 0.5 & 27 \\
\hline Little millet & 7.7 & 7.6 & 1.5 & 9.3 & 17 \\
\hline Barnyard millet & 11.2 & 10.1 & 4.4 & 15.2 & 11 \\
\hline Rice & 6.8 & 0.2 & 0.6 & 0.7 & 10 \\
\hline Wheat & 11.8 & 1.2 & 1.5 & 5.3 & 41 \\
\hline Source: Prashant et al $(2015)$ & & & &
\end{tabular}

Source: Prashant et al (2015)

\section{CONCLUSIONS}

The design, advancement and piloting of Proso millet De-husker showed good results for simplification of processing of Proso millet which is one of the major constraints for Proso millet growers in the high mountains of Karnali Province. It can reduce the work load and time for postharvest processing of Proso millet. It is economically sound with respect to traditional method of 
de-husking using human labor. The newly designed Proso Millet de-husker could be the processing alternative that save time and reduce women's drudgery significantly in most remote marginal region of Nepal such as Humla, where farmers have no access to improved machinery for mechanical processing and women are most vulnerable in terms of food insecurity and high drudgery. The machine has provided a potential opportunity to save time, reduce drudgery and cost of processing and thereby promoting conservation, production and improving the value chain of Proso millet.

\section{ACKNOWLEDGMENTS}

The authors are grateful to NARC, LI-Bird site officeHumla, Local crop project for financing and making the arrangement to develop and disseminate technology to the project sites.

\section{REFERENCES}

Balasubramanian S, R Viswanathan. 2010. Influence of moisture content on physical properties of minor millets.Journal of food science and technology. 47: 279-284. DOI: 10.1007/s13197-010-0043-Z

Bhandari GR, BK Joshi, D Gauchan, B Bhandari and S Panta. 2020. Simplifying the traditional processing system millets. In:Good Practices for Agrobiodiversity Management (BK, Joshi, D Gauchan, B Bhandari and D Jarvis, eds). NARC, LI-BIRD and Bioversity International; Kathmandu, Nepal.

DHAN Foundation. 2019. Assessment of Existing Small Millet Processing Equipment in India. Report of theDHAN Foundation and McGill University.

Joshi BK and KH Ghimire. 2015. Proso millet cultivation and seed production technology. Briefing paper 4. LIBIRD, NAGRC, DoA and Bioversity International, Nepal (in Nepali language).

Joshi BK, P Ojha, D Gauchan, KH Ghimire, and HB KC. 2020. Nutritionally Unique Native Crop Landraces from Mountain Nepal for Geographical Indication Right. In: Traditional Crop Biodiversity for Mountain Food and Nutrition Security in Nepal (D Gauchan, BK Joshi, B Bhandari, HK Manandhar and DI Jarvis, eds). Tools and Research Results of UNEP GEF Local Crop Project, Nepal; NARC, LI-BIRD and the Alliance of Bioversity International and CIAT; Kathmandu, Nepal (in this book).

Joshi BK, R Shrestha, IP Gautam, AP Poudel and TP Gotame. 2019. Neglected and Underutilized Species (NUS), and Future Smart Food (FSF) in Nepal. National Agriculture Genetic Resources Center (NAGRC, National Genebank), NARC, Khumaltar, Kathmandu, Nepal.

Modak and Bapat 1994. Formulation of a generalized experimental model for a manually driven flywheel motor and its optimization. Applied Ergonomics 25(1):199-122.

Parajuli A, A Subedi AR Adhikari, SR Sthapit, BK Joshi, D Gauchan and BR Sthapit. 2017. Baseline survey report: III. Chhipra, Humla. Integrating traditional crop genetic diversity into technology: Using a biodiversity portfolio against unpredictable environmental change in the Nepal Himalayas. Pokhara (Nepal): LI-BIRD/NARC/Bioversity International.

Patil Megha, AK Gupta, Parv Nayak . 2018. Design, development and performance evaluation of minor millet de-husker. International Journal of Farm Sciences. 8:63-69. DOI: http://dx.doi.org/10.5958/22500499.2018.00015.0

Prashant, S Suryawanshi, R Patil. 2015. Development of Millet De-Husking Machine. International Journal of Engineering Research \& Technology 3: Issue 17. https://www.ijert.org/development-of-millet-dehusking-machine

Rawat S, S Pant, N Pudasaini. 2019. Dudhe chino (Milky Proso millet): Introduction and cultivation practices, LI-BIRD, NAGRC, DoA, Bioversity International Nepal, Flyer 13.

||------||------|-|| 